\title{
Preoperative and postoperative evaluation of airways compression in pediatric patients with 3-dimensional multislice computed tomographic scanning: Effect on surgical management
}

Virginie Lambert, MD, anne Sigal-Cinqualbre, MD, ${ }^{\mathrm{b}}$ Emre Belli, MD, ${ }^{a}$ Claude Planché, MD, ${ }^{a}$ Régine Roussin, $\mathrm{MD}^{\mathrm{a}}$ Alain Serraf, MD, PhD, ${ }^{a}$ Jacqueline Bruniaux, MD, ${ }^{a}$ Claude Angel, MD, and Jean-François Paul, MD

From the Pediatric Cardiology and Cardiac Surgery Department ${ }^{\mathrm{a}}$ and the Radiology Department, ${ }^{\mathrm{b}}$ Marie Lannelongue Hospital, Le Plessis-Robinson, France.

Received for publication July 9, 2004; revisions received Aug 4, 2004; accepted for publication Aug 5, 2004.

Address for reprints: Virginie Lambert, MD, Centre Chirurgical Marie-Lannelongue, 133 Avenue de la Résistance, 92350 Le PlessisRobinson, France (E-mail: vlambert@ccml. com).

J Thorac Cardiovasc Surg 2005;129:1111-8 $0022-5223 / \$ 30.00$

Copyright $\odot 2005$ by The American Association for Thoracic Surgery

doi:10.1016/j.jtcvs.2004.08.030
Objectives: Surgical management of airway compression of vascular origin requires an accurate analysis of anatomy and various mechanisms of compression. This study assessed the usefulness of 3-dimensional computed tomographic scanning in the preoperative and postoperative evaluation of airways compression in a pediatric population.

Methods: Thirty-seven consecutive patients (median age, 4 months) were examined with multislice 3-dimensional computed tomographic scanning: 18 patients before surgical treatment of anomalies of vascular rings, 2 patients because of respiratory symptoms after repair of esophageal atresia, and 17 patients because of persisting respiratory symptoms or prolonged mechanical ventilation after cardiac surgery for congenital heart disease.

Results: The procedure was successful, with high-quality diagnostic imaging obtained in all cases without any complications. The anatomy and relationship between the vascular arches and airways was analyzed in all referred patients with vascular arch anomalies confirmed on the basis of the surgical findings, and this helped the surgeon to plan the procedure and choose the best approach. After cardiac surgery, the airway and vascular structures involved and the mechanism of compression were specified in all but one case, and the 3-dimensional computed tomographic scan serves as an important tool for deciding whether to perform reoperation on patients requiring prolonged mechanical ventilation.

Conclusion: Three-dimensional computed tomographic scanning is a safe, fast, and noninvasive method useful for accurately analyzing the mechanisms of airway compression of vascular origin and thus possible improving the surgical management of pediatric patients.

$\mathrm{S}$ urgical management of airway obstruction related to cardiovascular compression requires an accurate analysis of anatomy and various mechanisms of compression. Congenital vascular anomalies with or without associated intracardiac disease are a common cause of airway compression, and other mechanisms might be observed during the postoperative period of cardiac surgery, ${ }^{1}$ especially in infants, who might require prolonged mechanical ventilation. Bronchoscopy confirms the extrinsic and vascular nature of a tracheobronchial compres$\operatorname{sion}^{2}$ but fails to provide some information about the anatomic relationship between airways and vessels. Recently, noninvasive methods, such as magnetic resonance imaging (MRI) and spiral computed tomographic (CT) scanning with 3-dimensional imaging (3D-CT), have been shown to produce high-quality diagnostic imaging in patients with congenital heart disease and airway obstruction. ${ }^{3-6}$ This study evaluated the usefulness of 3D-CT for the surgical management of tracheobronchial 
compressions of vascular origin in pediatric patients.

\section{Patients and Methods \\ Patients}

Between 2001 and 2004, 37 consecutive patients (20 male and 17 female patients) were examined in Marie-Lannelongue Hospital with 3D-CT for preoperative or postoperative tracheobronchial compression of vascular origin. Median patient age was 4 months (range, 15 days to 13 years), and median patient weight was $6.5 \mathrm{~kg}$ (range, $1.2-25 \mathrm{~kg}$ ).

\section{Preoperative Evaluation}

Eighteen patients were examined before cardiac surgery, vascular surgery, or both. Thirteen patients were admitted for surgical treatment of anomalies of vascular rings suspected on an extrinsic and pulsate airway compression observed trough bronchoscopy, a fixed print noted with a barium esophagogram, or both. Two of these patients had coexistent intracardiac disease: truncus arteriosus in one patient and anatomically corrected transposition of the great arteries in the other. Five other patients, 2 of whom were receiving mechanical ventilation, were admitted for cardiac surgery for perimembranous ventricular septal defect (VSD; 3 patients), voluminous left ventricular rhabdomyoma (1 patient), and tetralogy of Fallot with absent pulmonary valve (1 patient). An associated airway obstruction was suspected on an unusually severe respiratory status and was revealed with a 3D-CT scanner.

Two additional patients without any cardiac or vascular disease were examined for respiratory symptoms related to tracheal compression occurring after surgical repair of type III esophageal atresia.

\section{Postoperative Evaluation}

In 17 patients, symptoms of airway compression developed after surgical intervention for congenital heart diseases (detailed in Table 1). The operations were complete anatomic or physiologic repairs in all but one patient, who had a palliative operation before the repair of a coarctation with VSD. The tracheobronchial compression was diagnosed after the operation, with bronchoscopy performed because of difficult or prolonged mechanical ventilation in 11 patients and persistent respiratory symptoms after extubation in 6 patients. The diagnosis was delayed after cardiac surgery from 1 day to 6 months (median, 7 days).

An additional 3D-CT scan was performed in 3 patients to check the postoperative result after the operation directed at relieving an obstruction because of persisting respiratory symptoms, with compression through bronchoscopy.

\section{D-CT Scanner Protocol}

Sedation was obtained in nonventilated patients with hydroxyzine administered orally associated with $0.3 \mathrm{mg} / \mathrm{kg}$ midazolam administrated intrarectally 1 hour before $3 \mathrm{D}-\mathrm{CT}$. All patients were monitored with pulse oxymetry, electrocardiography, and direct visualization through television. Sedation was well tolerated and without incident. General anesthesia was not necessary. CT examinations were performed first on 4-slice and then on 16-slice CT (Sensation 16; Siemens Medical Solutions, Erlangen, Germany). The examinations were performed at low kilovoltage $(80 \mathrm{kV})$; the tube current was adjusted according to the patient's weight and ranged from 17 to $90 \mathrm{mAs}$. Slice thickness was $1 \mathrm{~mm}$ on 4-slice $\mathrm{CT}$ and $0.75 \mathrm{~mm}$ on 16-slice CT. All patients received a standardized intravenous contrast injection at $2 \mathrm{~mL} / \mathrm{kg}$. The injection was performed with at a rate of 0.5 to $1.5 \mathrm{~mL} / \mathrm{s}$. The start delay before the beginning of the acquisition phase was 10 to 15 seconds, depending on the site of injection.

\section{Results}

The procedure was successful, with high-quality diagnostic imaging in all cases without any complications.

\section{Preoperative Evaluation}

The anatomy and relationship between the vascular arches and airways was analyzed in all patients referred for vascular arch anomaly: 1 had a circumflex aorta, 5 had a double aortic arch (Figure 1), and 4 had a right aortic arch, with descending aorta on the right side and compression by the left ligamentum arteriosum arising from a Kommerel diverticulum (Neuhauser anomaly) associated with a retroesophageal subclavian artery in 1 patient. In all patients the trachea appeared narrow in direct contact with the abnormal vessel, and an additional bronchial compression (left main bronchus [LMB] in 3 patients and right main bronchus [RMB] in 1 patient) was observed in 4 patients. Surgical repair was performed in all patients except 1 , who is awaiting surgical intervention at present, and consisted of the interruption of the vascular arch or in the section of the ligamentum arteriosum; the surgeon had confirmed 3D-CT findings in all cases. In 3 other patients, an aberrant left pulmonary artery (LPA) was diagnosed, compressing the carina. 3D-CT showed the origin and the course of the LPA and measured the distance between the LPA and the carina. In all patients the LPA was surgically uncrossed by using transection of the trachea. ${ }^{7}$

In 5 patients airway obstruction was diagnosed just before the surgical repair of congenital heart disease, and the mechanism was analyzed on 3D-CT in all cases: one patient with coarctation and VSD had a left bronchial compression by a dilated pulmonary artery (PA), which was completely resolved after a complete repair when the PA size had returned to normal. Two other patients with VSD had a right-sided aorta, with the ligamentum arteriosum compressing the trachea and the dilated PA compressing the $\mathrm{RMB}$. In one patient the ligamentum arteriosum was sectioned, and the defect was closed at the same time, relieving airway obstruction. The other patient, a premature infant with severe low birth weight, is awaiting surgical intervention. One patient had a voluminous left ventricular rhabdomyoma with mediastinal extension, and the 3D-CT scan showed that the LMB was stretched as the trachea shifted to the right side of the mediastinum. After the tumor resection, the relationship between the mediastinal vessels and the airways had become normal, and the airway obstruction was relieved. In the patient with tetralogy of Fallot with an 
TABLE 1

\begin{tabular}{|c|c|c|c|c|c|c|c|}
\hline Patient & Age & $\begin{array}{c}\text { Congenital } \\
\text { heart disease }\end{array}$ & Surgical procedures & Symptoms & $\begin{array}{c}\text { Delay } \\
\text { between } \\
\text { surgical } \\
\text { intervention } \\
\text { and 3D-CT }\end{array}$ & 3D-CT findings & Management \\
\hline 1 & $26 \mathrm{~d}$ & $\begin{array}{l}\text { TOF and } \\
\text { absent } \\
\text { pulmonary } \\
\text { valve }\end{array}$ & $\begin{array}{l}\text { Complete repair: VSD patch } \\
\text { closure, RVOT } \\
\text { reconstruction with 13- } \\
\text { mm Labcor tube, plasty } \\
\text { of PA reoperation } 20 \mathrm{~d} \\
\text { later for deinsertion of } \\
\text { VSD patch closure }\end{array}$ & $\begin{array}{l}\text { Recurrent R } \\
\text { pneumothorax }\end{array}$ & $3 d$ & $\begin{array}{l}\text { RMB compression } \\
\text { by pincer effect } \\
\text { between the } \\
\text { descending aorta } \\
\text { and the } R \text { upper } \\
\text { lobe artery }\end{array}$ & Aortopexy \\
\hline 2 & $1.6 \mathrm{mo}$ & $\begin{array}{l}\text { TOF, LPA } \\
\text { stenosis }\end{array}$ & $\begin{array}{l}\text { Complete repair: VSD } \\
\text { patch closure, RVOT } \\
\text { patch reconstruction } \\
\text { with LPA plasty }\end{array}$ & $\begin{array}{l}\text { L lung } \\
\text { atelectasia }\end{array}$ & $1 \mathrm{~d}$ & $\begin{array}{l}\text { Long stenosis of } \\
\text { LMB compressed } \\
\text { by LPA dilation }\end{array}$ & $\begin{array}{l}\text { Surgical } \\
\text { intervention } \\
\text { with L } \\
\text { thoracotomy: } \\
\text { diagnosis } \\
\text { nonconfirmed }\end{array}$ \\
\hline 3 & $14.5 \mathrm{mo}$ & $\begin{array}{l}\text { TOF with } \\
\text { pulmonary } \\
\text { atresia }\end{array}$ & $\begin{array}{l}\text { Complete repair: VSD } \\
\text { patch closure, RVOT } \\
\text { reconstruction with } \\
25-\mathrm{mm} \text { pulmonary } \\
\text { homograft, patch plasty } \\
\text { of bifurcation of PA }\end{array}$ & $\begin{array}{l}\text { Prolonged } \\
\text { mechanical } \\
\text { ventilation }\end{array}$ & $7 d$ & $\begin{array}{l}\text { Voluminous thrombus } \\
\text { dilating RPA, } \\
\text { which compressed } \\
\text { RMB }\end{array}$ & $\begin{array}{l}\text { Surgical } \\
\text { thrombectomy }\end{array}$ \\
\hline 4 & $3 \mathrm{mo}$ & TGA & $\begin{array}{l}\text { Arterial switch operation } \\
\text { and secondary } \mathrm{R} \\
\text { diaphragmatic plasty }\end{array}$ & $\begin{array}{l}\text { Respiratory } \\
\text { distress }\end{array}$ & $2.8 \mathrm{mo}$ & $\begin{array}{l}\text { LMB compression by } \\
\text { pincer effect } \\
\text { between } \\
\text { ascending aorta } \\
\text { and vertebral body }\end{array}$ & Aortopexy \\
\hline 5 & $6.5 \mathrm{mo}$ & $\begin{array}{l}\text { Coarctation } \\
\text { and VSD, } \\
\text { aortic valve } \\
\text { stenosis } \\
\text { with } \\
\text { annulus } \\
\text { hypoplasia }\end{array}$ & $\begin{array}{l}\text { RVOT replacement with } \\
21 \text {-mm pulmonary } \\
\text { homograft } 2 \text { y after Ross- } \\
\text { Kono operation }\end{array}$ & $\begin{array}{l}\text { Hypoxia, } \\
\text { wheezing, } \\
\text { persisting } \\
\text { dyspnea }\end{array}$ & $6.1 \mathrm{mo}$ & $\begin{array}{l}\text { Stretching of LMB on } \\
\text { the anterior side of } \\
\text { the descending } \\
\text { aorta related to } \\
\text { tracheal } \\
\text { displacement } \\
\text { toward the right of } \\
\text { the mediastinum, } \\
\text { PA dilation, aortic } \\
\text { arch dilation }\end{array}$ & $\begin{array}{l}\text { Plasty of aortic } \\
\text { arch: } \\
\text { replacement } \\
\text { of pulmonary } \\
\text { autograft } \\
\text { patch with a } \\
\text { Dacron patch }\end{array}$ \\
\hline 6 & $15 \mathrm{~d}$ & $\begin{array}{l}\text { Taussig-Bing } \\
\text { malformation } \\
\text { and } \\
\text { coarctation }\end{array}$ & $\begin{array}{l}\text { Complete repair: arterial } \\
\text { switch operation, VSD } \\
\text { patch closure, aortic } \\
\text { arch repair with Craaford } \\
\text { anastomosis }\end{array}$ & $\begin{array}{l}\text { Difficult and } \\
\text { prolonged } \\
\text { mechanical } \\
\text { ventilation }\end{array}$ & $6 \mathrm{~d}$ & $\begin{array}{l}\text { LMB compression by } \\
\text { posterior side of } \\
\text { ascending aorta }\end{array}$ & Aortopexy \\
\hline 7 & $30 \mathrm{mo}$ & $\begin{array}{l}\text { TOF with } \\
\text { severe PA } \\
\text { hypoplasia }\end{array}$ & $\begin{array}{l}\text { RVOT with a } 16-\mathrm{mm} \\
\text { Hancock tube and plasty } \\
\text { of the PA bifurcation } 2 \text { y } \\
\text { after complete repair: } \\
\text { VSD patch closure, RVOT } \\
\text { reconstruction with 12- } \\
\text { mm bovine jugular vein } \\
\text { tube and plasty of LPA } \\
\text { with the left atrial } \\
\text { appendage }\end{array}$ & $\begin{array}{l}\text { Refractory L } \\
\text { lung } \\
\text { atelectasia }\end{array}$ & $4 d$ & $\begin{array}{l}\text { LMB compression by } \\
\text { the left appendage } \\
\text { and the distal part } \\
\text { of the tube }\end{array}$ & $\begin{array}{l}\text { Plasty of left } \\
\text { atrial } \\
\text { appendage }\end{array}$ \\
\hline
\end{tabular}


TABLE 1. Continued

\begin{tabular}{|c|c|c|c|c|c|c|c|}
\hline Patient & Age & $\begin{array}{c}\text { Congenital } \\
\text { heart disease }\end{array}$ & Surgical procedures & Symptoms & $\begin{array}{c}\text { Delay } \\
\text { between } \\
\text { surgical } \\
\text { intervention } \\
\text { and 3D-CT }\end{array}$ & 3D-CT findings & Management \\
\hline 8 & $5.5 \mathrm{mo}$ & $\begin{array}{l}\text { Aortic arch } \\
\text { interruption }\end{array}$ & $\begin{array}{l}\text { Complete repair: PA } \\
\text { debanding and VSD } \\
\text { patch closure } 4 \text { mo after } \\
\text { palliation (aortic arch } \\
\text { repair with Craaford } \\
\text { anastomosis and PA } \\
\text { banding) }\end{array}$ & $\begin{array}{l}\text { Refractory L } \\
\text { lung } \\
\text { atelectasia }\end{array}$ & $1 \mathrm{~d}$ & $\begin{array}{l}\text { LMB compression by } \\
\text { descending aorta } \\
\text { related to trachea } \\
\text { and carina } \\
\text { displacement } \\
\text { toward the right of } \\
\text { the mediastinum }\end{array}$ & Aortopexy \\
\hline 9 & $15 d$ & $\begin{array}{l}\text { TGA, VSD, } \\
\text { PA } \\
\text { stenosis, } \\
\text { dextrocardia }\end{array}$ & $\begin{array}{l}\text { Central anastomosis } \\
\text { between innominate } \\
\text { artery and PA trunk using } \\
4 \mathrm{~mm} \text { PTFE tube }\end{array}$ & $\begin{array}{l}\text { Prolonged } \\
\text { mechanical } \\
\text { ventilation }\end{array}$ & $6 \mathrm{~d}$ & $\begin{array}{l}\text { Compression of the } \\
\text { LMB by a dilated } \\
\text { PA }\end{array}$ & $\begin{array}{l}\text { Medical } \\
\text { management } \\
\text { of the cardiac } \\
\text { overload } \\
\text { related to the } \\
\text { increased } \\
\text { flow through } \\
\text { the } \\
\text { anastomosis }\end{array}$ \\
\hline \multirow[t]{2}{*}{10} & $4 \mathrm{mo}$ & $\begin{array}{l}\text { Coarctation } \\
\text { and VSD } \\
\text { (prematurity, } \\
\text { multivisceral } \\
\text { failure) }\end{array}$ & $\begin{array}{l}\text { First stage: aortic arch } \\
\text { repair with } 6 \text {-mm PTFE } \\
\text { and PA banding }\end{array}$ & $\begin{array}{l}\text { Recurrent } \\
\text { episodes of } \\
\text { cyanosis }\end{array}$ & $4 \mathrm{mo}$ & $\begin{array}{l}\text { LMB compression by } \\
\text { biologic glue and } \\
\text { LPA stenosis }\end{array}$ & $\begin{array}{l}\text { Dissection of } \\
\text { the LMB and } \\
\text { lysis of } \\
\text { adhesions }\end{array}$ \\
\hline & $12 \mathrm{mo}$ & & $\begin{array}{l}\text { Second stage } 8 \text { mo later: } \\
\text { VSD patch closure, } \\
\text { Crawford anastomosis, } \\
\text { PA debanding, patch } \\
\text { plasty of RPA }\end{array}$ & Hypoxia & $20 \mathrm{~d}$ & $\begin{array}{l}\text { LMB compression by } \\
\text { pincer effect } \\
\text { between LPA and } \\
\text { the distal part of } \\
\text { aortic arch; severe } \\
\text { dilation of } \\
\text { ascending aorta }\end{array}$ & $\begin{array}{l}\text { Resection of } \\
\text { ascending } \\
\text { aortic } \\
\text { aneurysm, RV } \\
\text { outflow tract } \\
\text { reconstruction } \\
\text { with 16-mm } \\
\text { Hancock tube }\end{array}$ \\
\hline 11 & $2.5 \mathrm{mo}$ & $\begin{array}{l}\text { Type I } \\
\text { truncus } \\
\text { arteriosus, } \\
\text { severe } \\
\text { truncal } \\
\text { valve } \\
\text { regurgitation }\end{array}$ & $\begin{array}{l}\text { Complete repair: VSD } \\
\text { patch closure, RVOT } \\
\text { reconstruction with } 11- \\
\text { mm Labcor tube }\end{array}$ & $\begin{array}{l}\text { R lung distention } \\
\text { during } \\
\text { mechanical } \\
\text { ventilation }\end{array}$ & $20 \mathrm{~d}$ & $\begin{array}{l}\mathrm{R} \text { intermedius lobe } \\
\text { bronchus } \\
\text { compression by } \\
\text { dilated RPA }\end{array}$ & $\begin{array}{l}\text { Aortic valve } \\
\text { replacement } \\
\text { with } \\
\text { mechanical } \\
\text { valve and } \\
\text { patch plasty } \\
\text { of LPA }\end{array}$ \\
\hline 12 & $12 \mathrm{mo}$ & $\begin{array}{l}\text { VSD, ductus } \\
\text { arteriosus }\end{array}$ & $\begin{array}{l}\text { Complete repair: VSD } \\
\text { patch closure, section of } \\
\text { ductus arteriosus }\end{array}$ & $\begin{array}{l}\text { Recurrent R } \\
\text { lung } \\
\text { atelectasia } \\
\text { during } \\
\text { mechanical } \\
\text { ventilation }\end{array}$ & $10 \mathrm{~d}$ & $\begin{array}{l}\mathrm{R} \text { intermedius lobe } \\
\text { bronchus and } \\
\text { Nelson lobe } \\
\text { bronchus } \\
\text { compression by } \\
\text { dilated RPA }\end{array}$ & $\begin{array}{l}\text { Medical } \\
\text { management }\end{array}$ \\
\hline 13 & $4.7 \mathrm{mo}$ & $\begin{array}{l}\text { Aortic arch } \\
\text { interruption }\end{array}$ & $\begin{array}{l}\text { Complete repair: VSD } \\
\text { patch closure, aortic } \\
\text { arch enlargement using } \\
\text { pulmonary autograft } \\
\text { patch }\end{array}$ & $\begin{array}{l}\text { Pulmonary } \\
\text { distress and } \\
\text { recoarctation } \\
3 \text { mo after the } \\
\text { operation }\end{array}$ & $3 \mathrm{mo}$ & $\begin{array}{l}\text { Recoarctation and } \\
\text { LMB compression } \\
\text { by pincer effect } \\
\text { between the } \\
\text { anterior side of the } \\
\text { descending aorta } \\
\text { and the posterior } \\
\text { side of the LPA }\end{array}$ & $\begin{array}{l}\text { Prolongation of } \\
\text { aortic arch } \\
\text { with a } \\
\text { cylindrical } \\
\text { patch issue of } \\
\text { ascending } \\
\text { aorta }\end{array}$ \\
\hline
\end{tabular}


TABLE 1. Continued

\begin{tabular}{|c|c|c|c|c|c|c|c|}
\hline Patient & Age & $\begin{array}{c}\text { Congenital } \\
\text { heart disease }\end{array}$ & Surgical procedures & Symptoms & $\begin{array}{c}\text { Delay } \\
\text { between } \\
\text { surgical } \\
\text { intervention } \\
\text { and 3D-CT }\end{array}$ & 3D-CT findings & Management \\
\hline 14 & $13.5 \mathrm{y}$ & $\begin{array}{l}\text { Univentricular } \\
\text { heart, PA } \\
\text { atresia }\end{array}$ & $\begin{array}{l}\text { Bicavobipulmonary } \\
\text { anastomosis with } \\
\text { an extracardiac } \\
\text { PTFE tube }\end{array}$ & $\begin{array}{l}\text { Immediate } \\
\text { postoperative } \\
\text { L lung } \\
\text { atelectasia }\end{array}$ & $1 \mathrm{~d}$ & $\begin{array}{l}\text { LMB compression by } \\
\text { pincer effect } \\
\text { between the } \\
\text { posterior side of } \\
\text { the ascending } \\
\text { aorta and the } \\
\text { anterior side of the } \\
\text { descending aorta }\end{array}$ & $\begin{array}{l}\text { Aortopexy; } \\
\text { secondary } \\
\text { stent } \\
\text { placement in } \\
\text { LMB }\end{array}$ \\
\hline 15 & $4 \mathrm{mo}$ & $\begin{array}{l}\text { Large } \\
\text { muscular } \\
\text { VSD }\end{array}$ & $\begin{array}{l}\text { Complete repair: VSD } \\
\text { patch closure }\end{array}$ & $\begin{array}{l}\text { Immediate } \\
\text { postoperative } \\
\text { L lung } \\
\text { atelectasia }\end{array}$ & $2 d$ & $\begin{array}{l}\text { Stretching of LMB } \\
\text { between the aorta } \\
\text { and the RPA } \\
\text { related to a } \\
\text { rotation of the } \\
\text { mediastinum }\end{array}$ & Aortopexy \\
\hline 16 & $3 \mathrm{mo}$ & $\begin{array}{l}\text { Coarctation } \\
\text { and VSD }\end{array}$ & $\begin{array}{l}\text { Complete repair: VSD } \\
\text { patch closure, } \\
\text { Crawford } \\
\text { anastomosis }\end{array}$ & $\begin{array}{l}\text { Persisting L lung } \\
\text { atelectasia }\end{array}$ & $9 \mathrm{~d}$ & $\begin{array}{l}\text { Stretching of LMB on } \\
\text { the anterior side of } \\
\text { the descending } \\
\text { aorta related to } \\
\text { tracheal } \\
\text { displacement } \\
\text { toward the right of } \\
\text { the mediastinum, } \\
\text { PA dilation }\end{array}$ & $\begin{array}{l}\text { Medical } \\
\text { management }\end{array}$ \\
\hline 17 & $3 \mathrm{mo}$ & $\begin{array}{l}\text { Cor triatriatum } \\
\text { and } \\
\text { abnormal } \\
\text { arising of } \\
\text { the RPA } \\
\text { from the } \\
\text { ascending } \\
\text { aorta }\end{array}$ & $\begin{array}{l}\text { Complete repair: } \\
\text { reimplantation or } \\
\text { RPA on PA trunk, } \\
\text { resection of left } \\
\text { atria membranous }\end{array}$ & $\begin{array}{l}\text { Persisting } \\
\text { respiratory } \\
\text { symptoms }\end{array}$ & $10 \mathrm{~d}$ & $\begin{array}{l}\text { Stretching of the } \\
\text { LMB on the } \\
\text { anterior side of the } \\
\text { descending aorta } \\
\text { related to tracheal } \\
\text { displacement } \\
\text { toward the right of } \\
\text { the mediastinum }\end{array}$ & $\begin{array}{l}\text { Lysis of } \\
\text { adhesions }\end{array}$ \\
\hline
\end{tabular}

$T O F$, Tetralogy of Fallot; $V S D$, ventricular septal defect; $R V O T$, right ventricular outflow tract; $R V$, right ventricular; $P A$, pulmonary artery; $R$, right; $R M B$, right main bronchus; $L P A$, left pulmonary artery; $L M B$, left main bronchus; $R P A$, right pulmonary artery; $P T F E$, polytetrafluoroethylene.

absent pulmonary valve, the 3D-CT scan showed both the RMB and LMB to be compressed by a severely dilated PA in an anteroposterior plane, as well as in a superoinferior plane. Complete repair of the tetralogy of Fallot was associated with a plasty of both PAs; the vascular compression was relieved despite persisting respiratory symptoms related to bronchomalacia.

Among patients who underwent surgical repair of the esophageal atresia, one had a moderate tracheal compression by the innominate artery and was medically managed, and the other had a tracheal compression by the aortic arch related to a displacement toward the right side of the mediastinum associated with an anteroposterior tracheal compression by the innominate artery. An aortopexy was then performed with a good long-term result.

\section{Postoperative Evaluation}

Significant airway compression complicated the surgical course of 17 patients with congenital heart disease. The clinical data and the mechanism of compression shown with 3D-CT are summarized in Table 1. One patient had airway obstruction, making extubation impossible after both the palliative operation and the complete repair of coarctation associated with VSD. Most patients had a direct bronchial compression (RMB in 1 patient, right intermedius bronchus in 2 patients, and LMB in 6 patient) caused by a dilated PA secondary to an important left-to-right shunt (3 patients), a PA patch plasty (1 patient), or a voluminous thrombus (1 patient). Other causes of compression were the descending (1 patient) or ascending (1 patient) aorta, a tube placed on the right ventricular outlet (1 patient), and biologic glue (1 

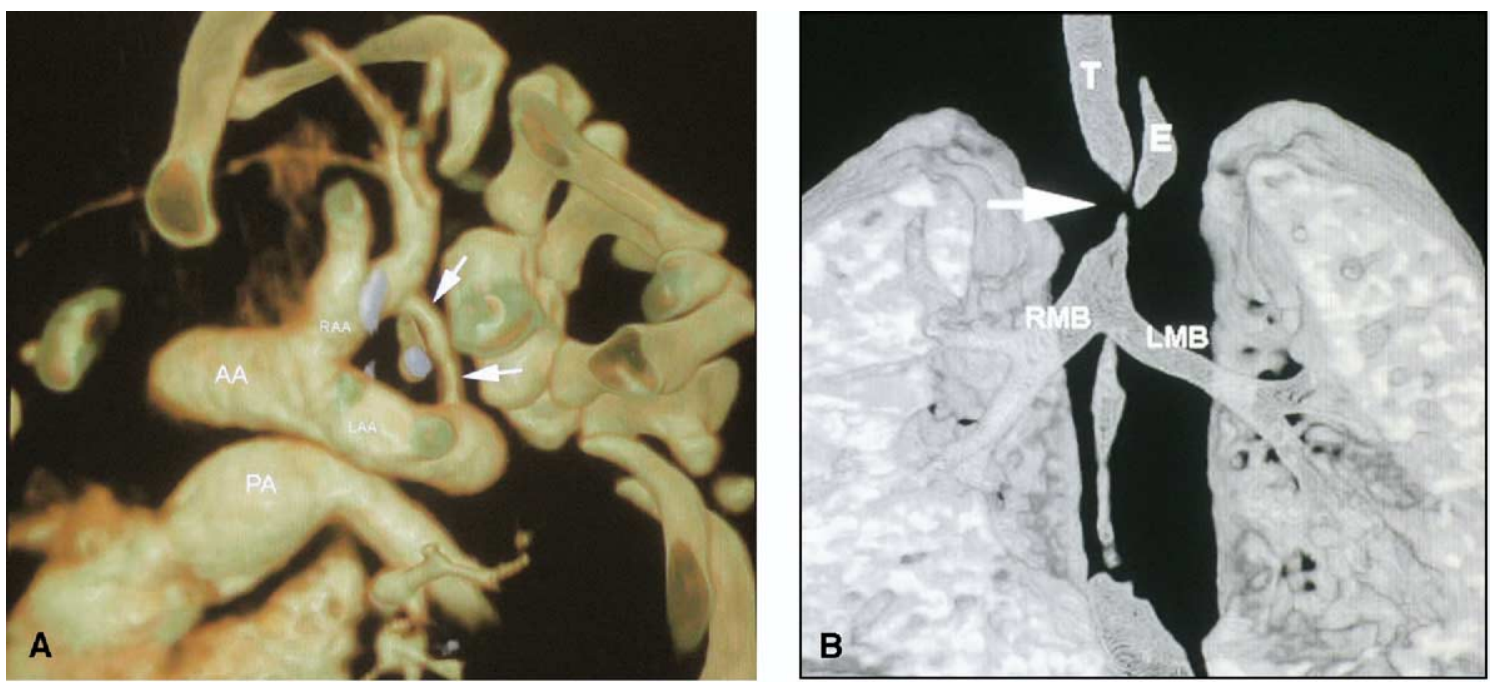

Figure 1. Double aortic arch. 3D-CT showed an unusual form, with hypoplasia of the right arch (A) severely compressing the trachea. The right and left main bronchi appear free of compression (B). $A A$, Ascending aorta; $E$, esophagus; $L A A$, left aortic arch; $L M B$, left main bronchus; $P A$, pulmonary artery; $R A A$, right aortic arch; $R M B$, right main bronchus; $T$, trachea.

patient). In 5 patients the LMB or RMB was pinched between 2 of these vessels (the PA, the ascending and descending aorta) or between the ascending aorta and a vertebral body. In 3 additional patients the LMB appeared stretched because of a displacement of the trachea toward the right side of the mediastinum. All patients, except 2 who were medically managed, underwent a reoperation to relieve the bronchial compression. 3D-CT findings were confirmed by the surgeon in all but one patient.

Furthermore, a 3D-CT scan was performed to check the results of the operation after uncrossing of the aberrant LPA. In one patient symptoms of compression persisted, making extubation impossible, and the postoperative bronchoscopic examination showed an extrinsic and pulsate compression of the anterior side of the trachea. The 3D-CT scan showed that the distal trachea was compressed anteriorly by the LPA, and a second operation was required. The PA trunk was shortened, and the compression was relieved by the downward displacement of the LPA (Figure 2).

\section{Discussion}

Our study demonstrated the value of 3D-CT imaging for the management of a pediatric population with airway compression of a vascular origin.

In preoperative evaluation 3D-CT appears useful for planning the operation by providing most of the necessary information that is not provided by other techniques. The diagnosis workup of children with suspected tracheal or bronchial compression includes chest radiography and bronchoscopy, and until recently, barium esophagography, echo- cardiography, and angiography were used to prove the involvement of abnormal vascular arches. ${ }^{8}$ In patients with respiratory symptoms, bronchoscopic examination and barium esophagography are performed as first-line diagnostic tools. Bronchoscopy visualizes the compression and confirms its extrinsic and vascular nature ${ }^{2}$ but fails to specify the anatomic relationship within the thorax. Barium esophagography is safe and easy to realize, but the fixed print assessing the compression by an abnormal vascular ring provides no information regarding vascular anatomy. Echocardiography might help in the diagnosis of abnormal vascular arch but provides only bidimensional imaging and fails to show the area of airway compression. These techniques of diagnosis appear to no longer be enough preoperative guidance for vascular ring operations, and 3D-CT has become the standard of care because it offers the advantages of being a noninvasive method and providing 3-dimensional information.

Various anatomic forms of vascular arch anomalies have been described ${ }^{9}$ and were recognized through 3D-CT imaging in our population: double aortic arch, Neuhauser anomaly, circumflex aorta, retroesophageal subclavian artery, and aberrant LPA were accurately visualized in all patients, and their relationships with the airways were analyzed. Because these anomalies were poorly tolerated, surgical intervention was mandatory. The aim of surgical treatment is to relieve the constriction by the vascular arch by dividing and opening it, thus correcting the tracheal and esophageal compression. An accurate preoperative evaluation of the anomaly is necessary to obtain the best result. 

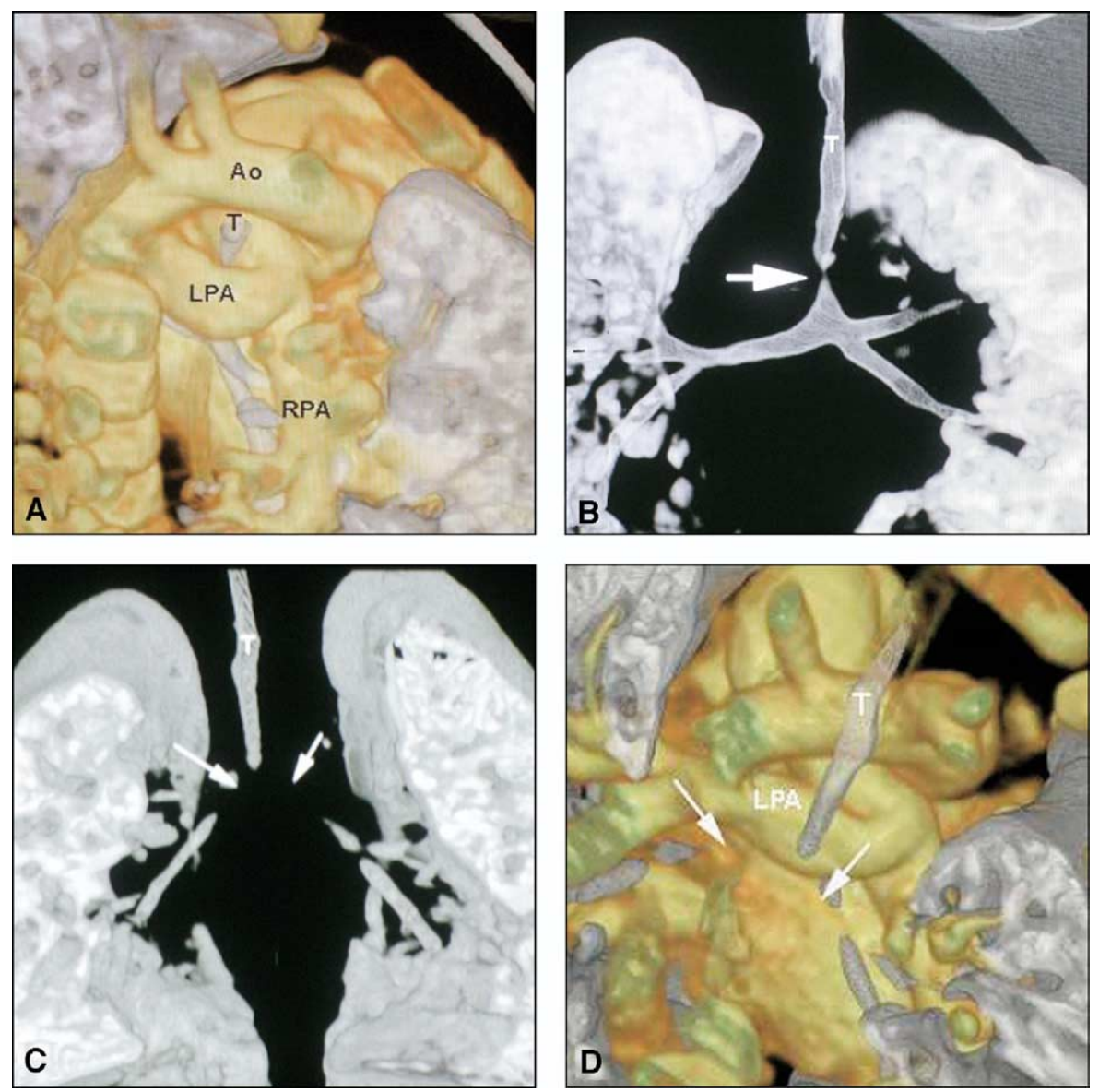

Figure 2. Aberrant left pulmonary artery. Preoperative evaluation with 3D-CT revealed an aberrant left pulmonary artery (A) responsible for tracheal compression (B). After repair, the 3D-CT scan showed severe persisting compression of the anterior side of the trachea (C) by the left pulmonary artery (D). Ao, Aorta; $L P A$, left pulmonary artery; $R P A$, right pulmonary artery; $T$, trachea.

The 3-dimensional reconstructed images obtained with 3D-CT allow surgeons to visualize the vessel responsible for the compression and analyze both its size and the arteries arising from the aortic arches, thus helping them to choose the best operative approach and to plan a surgical procedure. In our study the operative findings had confirmed 3D-CT data in all cases of vascular arch anomaly.

After vascular or cardiac surgery, the cause of respiratory difficulties in the postoperative period might be difficult to understand. It is generally thought to be secondary bronchomalacia, and these conditions are medically managed with prolonged assisted ventilation, but the symptoms of residual compression might be similar. A complication of surgical repair of an aberrant LPA, as previously described, ${ }^{10}$ was detected on the postoperative 3D-CT scan in one patient who required a reoperation, relieving an anterior compression of the trachea by the uncrossed LPA. On the other hand, 3D-CT scanning had eliminated the residual compression responsible for persisting respiratory symptoms after repair of tetralogy of Fallot with pulmonary valve agenesia, and the patient was successfully managed medically.

Major airway obstruction might complicate the natural and surgical course of children after thoracic surgery performed for congenital diseases, as well as for esophageal atresia. ${ }^{11,12}$ These authors have described some clinical situations with tracheal compression, bronchial compression, or both occurring before or after surgical intervention for congenital heart disease, with the diagnosis being assessed by means of tracheography, ${ }^{11}$ bronchoscopy, angiography, and standard thoracic CT. ${ }^{12}$ To the best of our knowledge, our 3D-CT study is the first to accurately analyze the causes of airway compression after thoracic surgery. Various mechanisms of compression were observed in our population. The most frequent was a direct conflict between the airways and adjacent structures, vessels, pros- 
thetic tubes, or biologic glue. A dilated PA compressing the airway has already been described ${ }^{13}$ and was related in our patients to a chronic left-to-right shunt, an absent pulmonary valve associated with some anatomic forms of tetralogy of Fallot, or circumstances after patch PA plasty. In one patient at the beginning of our experience, a left bronchial compression caused by PA dilation after LPA plasty was noted on 3D-CT scans, and a reoperation with a left thoracotomy approach was chosen to relieve the obstruction, but the surgical findings did not confirm 3D-CT data. The patient could be extubated with a good tolerance after medical management. Other mechanisms of airway compression were described by the surgeons during the operation directed at relieving obstruction. ${ }^{12,13}$ In accordance with these authors, we have observed airway obstruction caused by displacement toward the right side of the mediastinum, which induced a pincer effect between 2 mediastinal structures or a stretching of the bronchus. These anomalies were accurately visualized on 3D-CT imaging in our study and were in accordance with the surgical findings.

Among noninvasive methods, MRI is an alternative to 3D-CT, and the benefits have been shown in the imaging of congenital cardiac anomalies, ${ }^{6}$ as well as aortic arch anomalies, and their effects on the airway. ${ }^{14}$ For some authors, MRI is considered as the gold standard in the evaluation of vascular arches,${ }^{15}$ but the quality of imaging is affected by respiratory breath motions. Although breath holds were achieved in ventilated patients through suspended ventilation, sectioning between successive breath holds is less reproducible in conscious patients, especially in infants who required profound sedation or general anesthesia. ${ }^{6,14}$ All patients in our study had respiratory symptoms, and profound sedation might increase the risk of impairment of functional status and the necessity of assisted ventilation. In infants we used light sedation, which was well tolerated and allowed them to decrease anxiety related to the procedure. 3D-CT was performed in quiet or sleeping infants, and the speed of imaging acquisition contributed to the production of high-quality diagnostic imaging. One of the most important advantages of MRI, especially in a pediatric population, is the absence of radiation exposure. The risk related to radiation exposure is a major concern, especially in childhood. In our institution, according to the ALARA (As Low As Reasonably Achievable) principle, CT examinations in children are performed at low kilovoltage (ie, $80 \mathrm{kV}$ instead of $120 \mathrm{kV}$, the standard kilovoltage setting). Reducing the kilovoltage from 120 to $80 \mathrm{kV}$ decreases the radiation dose by $65 \%$ at a constant-current tube setting because the radi- ation dose varies with the square of the kilovoltage. All our examinations attained diagnostic quality with this lowkilovoltage, weight-adapted protocol.

In conclusion, 3D-CT appears to be a safe, fast, and noninvasive method useful for accurately identifying vascular anatomy before the repair of anomalies of the vascular arches, helping the surgeon to plan the surgical procedure and to choose the best approach. Furthermore, 3D-CT analyzes the mechanism of airway compression of vascular origin after cardiac surgery and serves as an important tool for deciding whether to do a reoperation in patients requiring prolonged mechanical ventilation.

\section{References}

1. DeLorimier AA, Harrison MR, Hardy K, Howell LJ, Adzick NS. Tracheobronchial obstruction in infants and children. Ann Surg. 1990; 212:277-89.

2. Binet JP, Langlois J. Aortic arch anomalies in children and infants. J Thorac Cardiovasc Surg. 1977;73:248-52.

3. Kauczor HU, Wolcke B, Fischer B, Mildenberger P, Lorenz J, Thelem M. Three-dimensional helical CT of the tracheobronchial tree: evaluation of imaging protocols and assessment of suspected stenoses with bronchoscopic correlation. AJR Am J Roentgenol. 1996;167:419-24.

4. Sagy M, Poustchi-Amin M, Nimkoff L, Silver P, Shikowitz M, Leonidas JC. Spiral computed tomographic scanning of the chest with three-dimensional imaging in the diagnosis and management of paediatric intrathoracic airway obstruction. Thorax. 1996;51:1005-9.

5. Paul JF, Lambert V, Losay J, et al. Three-dimensional multislice CT scanner: value in patients with pulmonary atresia with ventricular septal defect. Arch Mal Coeur. 2002;95:427-32.

6. Razavi RS, Hill DL, Muthurangu V, et al. Three-dimensional magnetic resonance imaging of congenital cardiac anomalies. Cardiol Young. 2003;13:461-5.

7. Jonas RA, Spevak PJ, McGill T, Castaneda AR. Pulmonary artery sling: primary repair by tracheal resection in infancy. $J$ Thorac Cardiovasc Surg. 1989;97:548-50.

8. Woods R, Sharp R, Holcomb G, et al. Vascular anomalies and tracheoesophageal compression: a single institution's 25-year experience. Ann Thorac Surg. 2001;72:434-9.

9. Langlois J, Binet JP, De Brux JL, Hvass U, Planché C. Aortic arch anomalies. Amsterdam, The Netherlands: Elsevier Science Publishing Co, Inc; 1991.

10. van Son JA, Hambsch J, Haas GS, Schneider P, Mohr FW. Pulmonary artery sling: reimplantation versus antetracheal translocation. Ann Thorac Surg. 1999;68:989-94.

11. Corno A, Giamberti A, Giannico S, et al. Airway obstructions associated with congenital heart disease in infancy. J Thorac Cardiovasc Surg. 1990;99:1091-8.

12. Robotin MC, Bruniaux J, Serraf A, et al. Unusual forms of tracheobronchial compression in infants with congenital heart disease. J Thorac Cardiovasc Surg. 1996;112:415-23.

13. Corno A, Picardo S, Ballerini L, Gugliantini P, Marcelletti C. Bronchial compression by dilated pulmonary artery. J Thorac Cardiovasc Surg. 1985;90:706-10.

14. Fleenor JT, Weinberg PM, Kramer SS, Fogel M. Vascular rings and their effect on tracheal geometry. Pediatr Cardiol. 2003;24:430-5.

15. Van Son J, Julsrud P, Hagler D, et al. Imaging strategies for vascular rings. Ann Thorac Surg. 2001;57:604-10. 